\section{ILIADEIA: UM PÉRIPLO DA ILÍADA TRADUZIDA NO BRASIL (ENSAIO FICCIONAL)}

\author{
Marcelo Tápia* \\ Recebido em: 15/04/2019 \\ Aprovado em: 06/05/2019
}

\begin{abstract}
RESUMO: O tema deste texto, "recriações da Ilíada como vias para o tradutor", é abordado mediante um ensaio ficcional, exercício criativo em que os personagens são tradutores brasileiros da epopeia homérica.

PALAVRAS-CHAVE: Homero; Ilíada; tradução poética; recriação.

$$
\begin{aligned}
& \text { ILIADELA: A PERIPLUS OF TRANSLATED } \\
& \text { ILIAD IN BRAZIL (FICTIONAL ESSAY) }
\end{aligned}
$$
\end{abstract}

* Professor do

Programa de Pós-

Graduação em

Letras Estrangeiras e

Tradução (LETRA),

Faculdade de

Filosofia, Letras e

Ciências Humanas,

Universidade de São

Paulo. Diretor da

Rede de Museus-Casas

Literários de São

Paulo.

marcelotapia954@gmail.com

\begin{abstract}
The subject of this paper ("re-creations of the Iliad as paths for the translator") is addressed through a fictional essay, a creative exercise in which the characters are Brazilian translators of the Homeric epic.
\end{abstract}

KEYWORDS: Homer; Iliad; poetic translation; re-creation.

\title{
INTRODUÇÃO
}

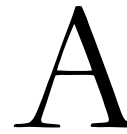

história das traduções da épica homérica no Brasil pode ser vista como um périplo: essa é a premissa deste trabalho, que se pretende uma experiência poético-paródica, com certo viés didático; quase um caderno de anotações de quem - býbris de aprendiz - ousa contar certos feitos de um modo um pouco seu. Para tanto, recorre reverentemente, à semelhança de Dante, a uma entrada no Inferno, acompanhado por um mestre; neste caso, o mundo adentrado será naturalmente, à maneira de Odisseu, o Hades, no qual estariam almas de tradutores nossos da Ilíada com que dialogamos, eu e aquele que me acompanha, Jaa Torrano; outros adquirem voz por meio de recursos da narrativa.

São postos em verso ditos fictícios das personagens, assim como falas que citam literalmente escritos seus ou são adaptações desses escritos que visam à sua conversão em medidas de verso. 
Estas se moldam, prioritariamente, a um padrão versificatório adotado pelos tradutorespersonagens, que também citam versos por eles traduzidos; a fala do narrador, minha, e do meu companheiro de viagem seguem, igualmente, padrões relacionados a modos nossos de composição. (Talvez se possa entrever, no exercício de versificação de citações, humilde memória do tempo em que se empregava o verso como veículo comum de transmissão de um pensamento ${ }^{1}$.

Assim, Manuel Odorico Mendes (1799-1864) diz em versos decassílabos, Carlos Alberto Nunes (1897-1990), em hexâmetros dactílicos (conforme o seu modo de adaptação silábico-acentual do hexâmetro grego: versos com cinco unidades ternárias e uma binária descendente) e Haroldo de Campos (1929-2003), em dodecassílabos (vali-me neste caso, por vezes, do hemistíquio hexassilábico; em outros, de diversa subdivisão da medida do verso). Vario o metro da voz do narrador, ora adotando o hexâmetro (nunesiano), ora as demais medidas, ora o esquema que cheguei a propor de transposição do verso homérico ao português: cinco a seis unidades acentuais por verso, com as tônicas em posições variadas, mas mantendo-se invariavelmente a "cláusula hexamétrica" (uma unidade ternária seguida de uma binária, ao final do verso). ${ }^{2}$ Jaa Torrano fala em versos livres.

As citações são referidas em notas, que informam acerca dos textos-fonte modificados nos versos e incluem referências e comentários adicionais que considerei pertinentes.

Se, por vingança, as Musas quiserem dizer-me o que fazer com os feitos alheios e vários, nelas terei de confiar sem confiar, na incerteza de ouvi-las, e dar à luz este turvo exercicio de fala espectral.

\section{ILIADEIA}

Musa, reconta-me os feitos dos bravos autores que deram voz brasileira a Homero; sussurra-me, agora, de Iliada e os tradutores daqui, pois a eles será dada a cena. O que disserem será, na verdade, o que captam ouvidos de pouco alcance, restrita acuidade, sujeitos à falta de entendimento, à mercê dos limites de psicografia falha. Errarei pelos mares undosos de praias alheias, para chegar a um lugar em que falem os vivos e os mortos, onde convivam os tempos e espaços diversos da escrita épica. Um solo profundo acharei neste plano distante, numa quebrada de mundos, numa encruzilhada de ditos lêmures, corpos e escritas serão imbricados no averno terreno.

\footnotetext{
${ }^{1}$ Como breve referência ao assunto, pode-se ver, por exemplo, Lopes (2003, p. 6).

${ }^{2}$ Veja-se o capítulo quarto da minha tese de doutorado, Proposição de referência rítmico-métrica associada a método tradutório (Tápia, 2012, p. 240-70).
} 
Evocarei Odorico, e Carlos Alberto, e Haroldo de Campos e mais os que derem o ar de sua graça na saga, conforme certa visão de contrários na ideia e iguais na tarefa, ou de coral de iguais em ideia e contrários em jeito de ser e ter a dizer em medidas distintas de versos sob um oceano ruidoso que leva à guerra de Ílion sacra, de Heitor e de Aquiles, heleno, e Agamêmnon e Príamo.

Ao chegar às portas do Hades, em companhia do mestre Jaa Torrano, que gentil atendeu ao pedido de guiar-me na viagem, evoco os espectros que, embora do Eliseu sendo dignos, possam nos dar entrevista especial à entrada do estranho Érebo, obscura, que por graça de Zeus Eleutério alcançamos (depois de ousar traspassar il segno - ir além dos limites). ${ }^{3}$

Quis ofertar meu sangue a fim de que as almas ganhassem sua força de vivos e cantassem em suas próprias palavras; mas o que há é um Hades reflexo, avesso, em que a seiva que me impulsiona é a delas; nutre-se o verso dos ditos prescritos a meus vigilantes sentidos: tais almas mantêm, por divina dádiva, a vida em seu verbo e em seu gesto, fazendo-se sombras de ativa presença.

A bem da noção de princípio-poder e princípio-começo, arkhé, manifesta-se todo o Jaa em força e sentido: "Pelas musas heliconíades comecemos a cantar"! A que, com certo ar de trânsito em transe, replico: "Por elas nos demos a cantar, por elas nos demos..."

\footnotetext{
${ }^{3}$ Referência aos versos de Bocaccio, relativos a Ulisses (Odisseu), em Amorosa visione - "per voler veder trapassò il segno / dal qual nessun poté mai in qua reddire" - (que ecoam Dante), o primeiro dos quais foi adotado por Haroldo de Campos como epígrafe de seu poema Finismundo. A última viagem (cujo tema é a morte de Odisseu tal como apresentada no Inferno dantesco - XXVI, 83-142). Ver Campos (1999, p. 55-9 e 352-53).

${ }^{4}$ Versos da Teogonia (Hesíodo, trad. de Jaa Torrano, 2003, p. 105). Sobre o início da Teogonia, diz o tradutor: "A primeira palavra que se pronuncia neste canto sobre o nascimento dos Deuses e do mundo é Musas, no genitivo plural. Por que esta palavra e não outra? Dentro da perspectiva da experiência arcaica da linguagem, por outra palavra o canto não poderia começar, não poderia se fazer canto, ter a força de trazer consigo os seres e os âmbitos em que são. É preciso que primeiro o nome das Musas se pronuncie e as Musas se apresentem como a numinosa força que são das palavras cantadas, para que o canto se dê em seu encanto" (ibid., p. 21).
} 
Odorico, o versi-heroico e conciso poeta, surge sintético, com ar lacônico, usando barrocas pérolas, de torcida forma, brilhantes, de águas fundas, colhidas no subsolo lodoso; indagado das contas de tom cerúleo, expele duros versos guardados de cor, escolhidos a dedo: "Não me apareças mais, quer ouses, velho, deter-te ou retornar; nem áureo cetro, nem ínfula do deus quiçá te valha.

Sai, não me irrites, se te queres salvo." ${ }^{5}$ Assim exordiou. Obediente e taciturno, tentei afastar-me do bardo agastado; o meu guia, porém, a meu favor interveio, suasivo:

"Oh, Manuel, não recuses, assim, a atender a meu diletante amigo; concede-lhe, mestre, uma fala branda."

Diz Odorico em resposta, com ar abrandado:

"Dada a alta prosopopeia do astucioso tradutor que me fala, cederei ao incômodo chamado. Pérolas cerúleas tenho colhido a fim de nutrir-me do que careço: a divinal beleza das palavras.

Da alma a poesia me fugiu celeste, nem na cítara mais dedilhar soube, desde que aqui mergulhei em ausência após julgar despiciendos meus dons."

Em vez de indagar do porquê de tão severo juízo, fiz libação de silêncio o mais respeitoso, como alimento ao espírito depreciativo, mais eficaz que o mais convincente elogio.

Reanimou-se o aedo, evocando a lira de Aquiles:

"Já no arraial dos Mirmidões o encontram a recrear-se na artefacta lira.

Que travessa une argêntea, insigne presa dos raros muros d'Etion: façanhas de valentes cantava, e só Pátroclo tácito à espera está que finde o canto."”

\footnotetext{
${ }^{5}$ Ilíada (HOMERO, trad. Odorico Mendes, 2008, p.45-6).

${ }^{6} \mathrm{O}$ último verso alude à opção tradutória de Odorico para verso do Canto IX da Iliada: "Dons não despiciendos lhe destinas" (Homero, trad. de Odorico Mendes, 2008, p. 325).

${ }^{7}$ Ilíada, IX, 149-154 (ibid.). A numeração dos versos da tradução de Odorico Mendes não corresponde à numeração dos versos do original grego.
} 
De novo me pus em mudez, desta vez elogiosa; farto de libações, ia o bardo saindo, quando retrocedeu e disse inquieto, bem seco: "Que urge? A que vindes? Bem que irado, amigos, exulto ao ver quaisquer humanos, vinde a que vierdes. Passo-vos a fala."

Eu, temeroso, lanço ao vento as palavras aladas:

"Concede dizer-me, pois, das fórmulas tuas, e, também, da síntese tão buscada, sem trégua."

Respondeu-me o escritor, em seguida, polipansábio:"

"Trato de verter epítetos com exatidão e nos lugares mais apropriados; isso feito, omito repetições: seriam enfadonhas. Se vertêssemos servilmente as repetições de Homero, deixava a obra de ser aprazível como é a dele; das infidelidades, a pior..." ${ }^{10}$ Sobre compósitos solicitei-o, prudente. Isto logo me disse, de funda memória: "Cumpre lutar com o original, temperando a iguaria co'os adubos que nos ministra cada língua, ou pedindo-as às entranhas, se preciso: o mais não é traduzir; é emendar ou corrigir o que não há mister emenda nem correção; é tirar aos leitores o [uma pausa segue-se] gosto de penetrar na Antiguidade."11

\footnotetext{
${ }^{8}$ Os versos adaptam os seguintes versos do Canto IX da Ilíada, na tradução de Odorico Mendes: "Que urge? A que vindes? Bem que irado, amigos, / exulto ao ver os Dânaos que mais prezo” (Homero, trad. de Odorico Mendes, 2008, p. 325, versos 358-359).

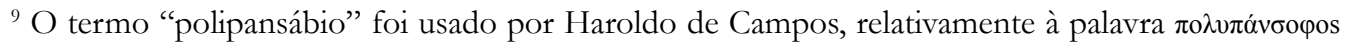
(polupánsophos), em sua tradução do "dito da Pitonisa délfica sobre a questão homérica" (Campos, 2002, p. 5-6).

${ }^{10}$ Os versos anotam trecho de notas de Odorico Mendes ao Canto I da Ilíada (Homero, trad. de Odorico Mendes, 2008, p. 873).

${ }^{11}$ Os versos anotam trecho de notas de Odorico Mendes ao Canto II da Ilíada (Homero, trad. de Odorico Mendes, 2008, p. 877).
} 
Ousadamente ingênuo, lanço-lhe as desaladas palavras:

"Como lês, Odorico, teu próprio verso de Homero?"

Diz-me o verbissintético autor, em resposta:

"Só posso anunciar como alguns meus versos

veem: 'macarrônico'12 ou pleno de

insucessos a uns pareço; 'pai

rococó', a outro vate que me

nutre, antiteticamente, nas noites

em que padeço de ouvir, sempre, sempre,

detrações de meus feitos, louvações

a meus defeitos, que devo expiar.

Mesmo de quem mais alento me trouxe

neste mundo profundo, ouvi ser

autor de soluções 'sesquipedais

e inaceitáveis'. ${ }^{13}$ Hei de conformar-me.”

À evocação de adjetivos ditados por Campos, a nós, visitantes do Érebo, resta uma bruma hesitante;

é quando inicia uma fala ressoante o Torrano:

"Fatum é nada \& nenhum evento necessariamente ser

o que é, mas necessariamente ser-\&-não", ${ }^{14}$

disse, biambíguo, enquanto se via,

sob luz súbita, que ele um tirso portava:

"As Tieteidas

filhas de Amigo Zeus

nutrizes de Dioniso

nos dão a lucidez

de inebriante raio." 15

Em risonha aparição, Haroldo irrompe com pena

de jade na mão, a grafar relembradas sentenças-

-sulcos em placa de vidro translúcido, acerca

do altivo e todo-ouvido vate Odorico:

"Muita tinta tem corrido p'ra depreciar

o Odorico tradutor, para reprovar-lhe

o preciosismo rebarbativo ou o mau gosto

de seus compósitos vocabulares. Mais

${ }^{12}$ Referência ao juízo crítico emitido por Silvio Romero acerca das traduções de Mendes, assim mencionado por Haroldo de Campos: "[...] monstruosidades, escritas em português macarrônico". Veja-se, acerca dessa citação e da qualificação "pai rococó”, dada a Odorico pelo poeta Sousândrade, bem como sobre a importância da obra do tradutor, Campos (2013).

${ }^{13}$ Referência a comentário de Haroldo de Campos (2013, p. 10).

${ }^{14}$ Citação de poema de Jaa Torrano $(2009$, p. 7).

${ }^{15}$ Citação de poema de Jaa Torrano (2017, p. 15). 
difícil seria, porém, reconhecer

que Mendes, admirável humanista, soube

desenvolver um sistema de tradução

coerente e consistente, em que seus vícios

(numerosos sem dúvida) são justamente

os vícios de suas qualidades, quando não

de sua época... Procurou reproduzir

as 'metáforas fixas', os característicos

epítetos homéricos,

inventando compósitos em português,

e muitas vezes extremando o paradigma.

É feliz na transcrição onomatopaica

do ruído do mar, uma constante incidência

na epopeia homérica:

'Muge horríssona vaga e o mar reboa, com sopro hórrido e ríspido encapelam

o clamoroso pélago [...]"'16

Sabedores do apreço de Campos às obras do tradutor, causou-nos pouca surpresa

o dito; mas o versi-heroico Odorico

exibe refeito ânimo, embora tivesse

o cenho agravado ao ouvir menção a seus vícios;

instigou-se a ponto de ofertar, generoso,

uma escrita de trégua, feita de angústia

antiga, apaziguada, nutrindo-nos de Ilíada compacta:

" $P$ Por teu bom pai, de um velho te apiades:

mais infeliz do que ele, estou fazendo

o que nunca mortal fez sobre a terra:

Esta mão beijo que matou meus filhos.'

De Peleu mais saudoso, o herói suspira, pega-lhe a destra e brando afasta o velho:

um de joelhos por Heitor pranteia;

outro chora seu pai, chora a Pátroclo:

de ambos o soluçar na tenda estruge." ${ }^{17}$

Afasta-se, após, o ereto, velocípede poeta, a mostrar a lepidez que preserva apesar dos pesares

e do tempo corrido dês que calou a

voz mortal; pela estância plutônica, então, se esvaece.

${ }^{16}$ A "fala" atribuída a Haroldo compõe-se de excertos de Campos, 2013.

${ }^{17}$ Ilíada, XXIV, 399-407 (Homero, trad. de Odorico Mendes, 2008, p. 857). 
Nova evocação da Musa surge, a seguir, na voz de Campos, aguda e melodicossoante: "A ira, Deusa, celebra do Peleio Aquiles, o irado desvario, que aos Aqueus tantas penas trouxe, e incontáveis almas arrojou no Hades de valentes, de heróis, espólio para os cães, pasto de aves rapaces: fez-se a lei de Zeus; desde que por primeiro a discórdia apartou o Atreide, chefe de homens, e o divino Aquiles."18

A discórdia, mênis, mostrou-se emergente, assim como a erronia, áte, a perdição que motiva deuses, heróis e aedos. É quando soa, distante, de onde não sei, a mélea voz de Silva Alvarenga, longe, longe dali, por um túnel ouvida: "Longe, longe daqui, vulgo profano, Que das musas ignoras os segredos.

Eu vi sobre rochedos, Onde nunca tocou vestígio humano, Alta deusa descer com fausto agouro Em branca nuvem realçada d'ouro.

Ah! Vem, formosa cândida verdade, Nos versos meus a tua luz derrama: $[\ldots]]^{\prime 19}$

Uma luz penetra o espaço, adensando-se; e assim surge, em foco, o verso homérico inscrito em lousa de vidro, cristal vislumbrado na névoa ("escrever no vidro / sentenças de vidro / / in / visíveis"20 - evoco linhas celestes de Haroldo, no turvo ambiente) em !bosque de eucaliptus! de vívido aroma: ${ }^{21}$

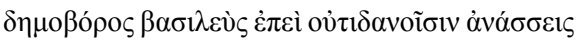
[demobóros basiléus, epei outidanoîsin anásseis],;2 desoculta ramagem de signos acordes tilinta. ${ }^{23}$ Acenando com os dedos, que portam a pena virente, passa Campos a evocar, de cor, o versiconciso

\footnotetext{
${ }^{18}$ Ilíada de Homero (trad. de Haroldo de Campos, 2002, p. 31).

${ }^{19}$ Silva Alvarenga (2005, p. 63).

${ }^{20}$ Os versos citados integram a parte 2 da seção "Signantia quasi coelum” (Campos, 1979, p. 36).

${ }^{21}$ A expressão "!bosque de eucaliptus!” é colhida na parte 2 de "Esboços para uma nékuia" (Campos, 1979, p. 91).

${ }^{22}$ Iliad, I, 231 (Homer, ed. Thomas W. Allen, 1920).

${ }^{23} \mathrm{O}$ verso incorpora citação de verso da parte 1 da seção "Signantia quasi coelum" ("desoculta ramagem de signos/ soa/ o acorde do uni/verso": Campos, 1979, p. 28).
} 
recriador maranhense: "Odorico traduz:

'Cobardes reges, vorador do povo', recuperando o demobóros com a sua fórmula paronomástica 'vorador do povo", ${ }^{24}$ diz; e em voz de alto pensar, murmura:

"Odorico, com efeito, é o patriarca da tradução criativa no Brasil, no seu intuito helenizante." ${ }^{25}$

O verso dele próprio ressoa em nossos ouvidos: "Devora-povo! Rei dos Dânaos? Rei de nada."' Dedicado a argumentar pelo labor tradutório, aponta: "O trocadilho entre Danaoi e outidanós se expande em paronomásia (dos DÂNAos/ de NADA). Lei da compensação, regra de ouro da tradução criativa... Atento aos revérberos sou. ${ }^{27}$ Em 'Aquiles, dor do povo', procurei explicitar a etimologia do nome Akhilleús. Pois o nome do herói da Ilíada procederia - conjetura - de Akhi-Laous, 'aquele cujo povo/exército tem dor'..." 28

Outros versos dele relembro, tendo-os em cópia: "Dá uma pausa à ira, Atreide. Eu próprio - eu sou quem te rogo: tira teu furor de sobre Aquiles: [...]." ${ }^{29}$ À audição dos versos, diz Haroldo: "A rima em eco entre 'ira' e 'tira' visa a reproduzir um efeito de orquestração interna do original: pầe teòn MÉNos / methéMEN kehólon. Procuro estar atento à microtessitura fônica, em pontos que geralmente escapam às demais traduções." ${ }^{30}$

\footnotetext{
${ }^{24}$ Veja-se Campos (1994, p. 14-15).

${ }^{25}$ Os versos provêm do seguinte fragmento do texto "Para transcriar a Ilíada": "Odorico, com efeito, é o patriarca da tradução criativa no Brasil, no seu intuito pioneiro de conceber um sistema coerente de procedimentos que lhe permitisse helenizar o português, em lugar de neutralizar a diferença do original, rasurando-lhe as arestas sintáticas e lexicais em nossa língua" (Campos, 1994, p. 12).

${ }^{26}$ Campos (1994, p. 16).

${ }^{27}$ Os versos provêm de: "Atento a todos esses revérberos, procurei reconstituir, sonora e semanticamente, com o máximo de economia, o jogo de palavras que nas traduções consultadas [de Odorico Mendes e Carlos Alberto Nunes] passou em branco" (Campos, 1994, p. 16). ${ }^{28}$ Ibid.

${ }^{29}$ Versos 282 a 284 do Canto I da Ilíada na tradução de Haroldo de Campos (Campos, 1994, p. 51). ${ }^{30}$ Os versos provêm de nota do tradutor aos versos 282-283 do Canto I da Ilíada (Campos, 1994, p. 20).
} 
“... como os fados mandam" / katà moîran", ${ }^{11}$ é o que

se ouve na voz de Jaa, ciente de mitos;

Haroldo explicita, a seguir, seu procedimento:

"Sim; não quis perder o matiz etimológico

alusivo ao destino (Moîra) na expressão..." ${ }^{32}$

Disponho-me a buscar, na luzente tela que trago

como bagagem, arquivos de citações recolhidas;

fazem-se imagem, em brancofluente cristal, enunciados

de Trajano Vieira, constante parceiro de Haroldo,

os quais proclamo, no ambiente translúcido, em linhas tangíveis:

"o apuradíssimo labor verbal de Homero

encontra, na tradução de Haroldo de Campos,

correspondências surpreendentes que fazem

dela um marco não só

da literatura de língua portuguesa.

Haroldo preferiu manter o mesmo número

de versos do grego e

preservar a misteriosa sonoridade

nominal, fazendo uso, aqui e ali, de

epítetos e de

expressões que esclarecem o significado

dos vocábulos." 33 Ao evocar Mnemosyne,

Haroldo põe-se a dizer os harmônicos versos:

"Eram Gláucia azul-mar e Tália florida; a ôndula

Cimodócea; a insular Neseia; a cavernícola

Espeia; Toa, nado-agílima; Hália, cinza-sal, olhos-redondos; Mélita, mel; Iera grácil;

Anfitóe circum-nadante e Ágave bem-nada;

Cimotóe, onda rápida; Acteia e Limnória;

Doto e seus dons; Proto, primícias; fértil Férusa;

Dexamene, cisterna-amena; Dinamene,

dínamo-fluente; a circum-próxima Anfinome;

Calianira, encanta-homens; Dóris; Panópeia,

pan-vidente; a gloriosa Galateia; Nemertes;

Apseude, Iânira, Ianassa, Climene, Caliâ-

-nassa, Maíra, Oriteia, Amátia - eis as Nereides

abissais, todas; [...]"34

${ }^{31}$ A citação refere-se à nota do tradutor (ibid.).

${ }^{32}$ Ibid.

${ }^{33}$ A citação provém de Vieira (Homero, trad. de Haroldo de Campos, 2002, p. 23-24).

${ }^{34}$ Versos 39-49 do Canto XVIII da Ilíada, conhecidos como o "catálogo das Nereides" (Homero, trad. de Haroldo de Campos, 2002, v. 2, p. 233). 
Segue-se uma pausa, durante a qual o poeta faz reticências no ar, multiecoante.

E, dirigindo-se a nós, envia palavras que planam: "espio o expiar; reflito sobre os reflexos, contemplo a vida devotada à poesia, ida, expio o fazer apenas pelo que fiz; não me é dada a fala desmorrida, renascida. ${ }^{35}$ Redigo o que me foi dado dizer."

E, da Ilíada de novo ocupando-se, toma o tema da mênis, a ira tenaz, a cólera, o irado desvario, a fúria ${ }^{36}$ de Aquiles, voz dando à fala de Agamêmnon ao chegarem a sua tenda Odisseu e Ájax, vindos do encontro com o Pelida: " "Dize-me Odisseu, multilouvado, aquéia glória, ele quer defender as naus do fogo ardente, ou - duro coração - disse não, todo-cólera?' Respondeu-lhe Odisseu, divo multissofrido: 'Agamêmnon, excelso Atreide, rei-dos-homens, ele, de fato, não quer aplacar a ira. Antes, mais e mais, empina e infla sua cólera. A ti, aos dons desdenha: com os Gregos, cuides tu de salvar os navios e o exército aqueu; ameaçou até mesmo se fazer ao largo com as naus bicurvadas, belos-bancos, tão logo faísque Éos, a Aurora. Pondera e propõe aos outros retornar à pátria: vencer Troia é impossível. Sobre ela Zeus, altissonante, estendeu a mão, dando força a seus guerreiros." ${ }^{37}$ Faz-se presente, então, o espectro nevoento, projeção de nossa vontade: a imagem do arguto Odisseu, o multívio herói, o Ninguém engenhoso; meditativo, proclama o Jaa em voz baixa: "Ninguém fica para semente. Ninguém remergulha no mesmo rio. Ninguém rouba a paz ao Ciclope \& fura-lhe o único olho." Quando se associa a métis, astúcia, a mé tis, ninguém, atinge-se o zênite, penso, proponho,

\footnotetext{
35 Alusão ao poema nascemorre, de Haroldo de Campos (1976).

${ }^{36}$ As diversas expressões que traduzem mênis, apresentadas em sequência, são adotadas pelos tradutores, na ordem: Odorico Mendes; Carlos Alberto Nunes e Christian Werner; Haroldo de Campos; André Malta.

${ }^{37}$ Ilíada, IX, 677-687 (Homero, trad. de Haroldo de Campos, 2002, p. 367-69).
} 
da eficiência poético-paronomástica, inconquistável;

só dá Ninguém: não tem pra ninguém - esse é o cara, o Ninguém; agudeza, ardil, o truque bem feito.

"André Malta que o diga, tendo-o bem dito" ${ }^{38}$ comenta Jaa, o mestre de ditos. Ao longe, afeito ao vagar odisseico, Haroldo relembra sua reescritura da morte do herói, contada por Dante, que o vira no Inferno:

$[\ldots]$

"Efêmeros sinais do torvelinho

Acusam-lhe o naufrágio -

Instam mas declinam

Soçobrados no instante.

$[\ldots]^{\prime 39}$

Mas, atrelado à Ilíada, revive a cena em que Ájax com o astuto compete, na prova proposta

pelo Pelida - à corrida dos jogos em honra de Pátroclo, fúnebre embate, ambos se postam: "A Atena, olhos-azuis, rogava Odisseu no íntimo: 'Deusa benigna, vem em socorro a meus pés!' Falou, súplice, e Palas Atena o escutou, fazendo-lhe mais ágeis membros e pés, braços também. E quando estavam por lançar-se ao prêmio, Ájax, à disparada, escorrega (empurrou-o Atena) e cai no esterco acumulado pelos bois altimugidores, abatidos por Aquiles, em honor de Pátroclo; enlameia-lhe Boca e nariz o estrume bovino! Arrebata A cratera Odisseu, o primeiro a chegar. Ájax recebe o touro e aferra-o pelo chifre, Cuspindo esterco. Volta-se então aos Argivos: 'Ó céus! Deu-me, decerto, a deusa um trança-pé; por Odisseu, há tempo, tem como desvelos de mãe, sustendo-o sempre. [...]"'40

Ouve-se ao longe, longe, o espectro do mestre Odorico:

"No extremo quase, em mente o Laercides

Ora: 'Auxílio, Minerva olhicerúlea!'

A deusa o atende; os membros lhe agilita, Pernas e mãos; já já no fim, transvia A Ajax, que sobre o esterco das mugentes

\footnotetext{
${ }^{38}$ Alusão ao tema do livro de André Malta (2018).

${ }^{39}$ Campos (1999, p. 58).

${ }^{40}$ Ilíada, XXIII, 769-784 (Homero, trad. de Haroldo de Campos, 2002, v. 2, p. 433).
} 
Vítimas imoladas ao Menécio,

Resvalando, enlameia a boca e as ventas.

Leva a cratera o paciente Ulisses;

Ajax do boi silvestre aferra os cornos,

A bosta escarra: 'Os pés falsou-me a deusa;

Ah! de Ulisses mãe terna o assiste sempre." 41

Isso disse ele. Sob revérberos breves do verso-galope

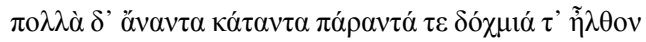

[pollà d'ánanta kátanta párantá te dókhmiá t'êlthon],

dissipa-se a figura de Campos, a transcriá-lo:

"multivão, rampa-acima, abaixo-rampa, aos flancos"... ${ }^{42}$

"A alma, como um sonho, bate as asas e voa", ${ }^{43}$

digo; entreolhamo-nos, eu e o Torrano, pacientes, à espera de nova visão numinosa no Hades;

surge, logo, o espectro de Nunes, o Carlos Alberto, que em hexâmetros deu-nos Virgílio e Homero.

Inicia sua fala com tréplica aos versos alheios:

"à de olhos glaucos, Atena, Odisseu do imo eleva uma súplica:

'Ouve-me, deusa, e auxilia-me; aos pés ligeireza me empresta!'

A fervorosa oração foi ouvida por Palas Atena:

Leves lhe torna os membros, os braços e as pernas robustas.

E quando estavam no ponto de o prêmio alcançar cobiçado,

o ágil Ajaz, a correr, escorrega - o trabalho de Atena -

no liso chão, onde esterco se via dos bois mugidores

que o divo Aquiles em honra do amigo dileto imolara:

ficam de estrume emboldeadros a boca e o nariz do guerreiro.

Ganha a cratera o divino e sofrido Odisseu, porque tinha sido o primeiro a chegar; leva Ajaz o boi forte dos campos.

Pondo-se junto do boi das campinas, do chifre lhe aferra, e a cuspinhar a espurcícia, aos valentes Aqueus se dirige: 'A escorregar obrigou-me, sem dúvida, a mesma deidade que, como mãe carinhosa, a Odisseu sempre ampara e auxilia". ${ }^{44}$

\footnotetext{
${ }^{41}$ Iliada, XXIII, 641-651 (Homero, trad. de Odorico Mendes, 2008, p. 825).

${ }^{42}$ Ilíada, XXIII, 116. A tradução do verso é atribuída a Campos por Trajano Vieira, em sua Introdução ao livro Ilíada de Homero (Homero, trad. de Haroldo de Campos, 2002, v. 1, p. 25). Outra é, no entanto, a versão publicada do verso; segue-se a sequência dos versos 116-118: “[...] caminham os mulos monteses (116)/ à frente; por veredas, seguiam-nos os homens (117)/ avante, de través, de flanco, a ré; [...]" (Homero, trad. de Haroldo de Campos, 2002, v. 2, p. 395).

${ }^{43}$ Referência, em minha tradução, ao verso 223 do Canto XI da Odisseia, de Homero.

${ }^{44}$ Ilíada de Homero em tradução em versos de Carlos Alberto Nunes (s.d., p. 510-11).
} 
O médico legista examina, com zelo e respeito, as três dimensões projetadas de imagem, em mesa ausente, do corpo ultrajado mas sempreintacto de Heitor, o troiano; - a dissecção não seria um ultraje, por certo, agora -, digo em meu íntimo ansioso de que secções não se dessem. Passa a dizer o poeta, com alta e pausada emissão, os dáctilos feitos ao modo do canto elevado de Homero: "Para o cadáver voltando-se, Aquiles divino, então, fala: 'Morre, que me acho disposto a acolher o Destino funesto logo que Zeus o quiser e as demais divindades eternas'. A hasta de bronze, depois de falar, do cadáver arranca, pondo-a de lado, e, também, a armadura sangrenta dos largos ombros lhe tira. Acorreram, então, numerosos Aquivos para admirar a imponência e a beleza do corpo de Heitor, sem que nenhum de feri-lo deixasse, ao passar pelo corpo." ${ }^{\prime 45}$

E, desejoso de pôr-se a aclarar o teor do trabalho, passa a falar-nos o Carlos Alberto, que ouvimos silentes: "E assim firmemos, portanto, como é o caráter dos versos épicos: são uniformes, há metro uniforme nos versos.

Interpretando o hexâmetro em termos de metro em língua nossa, veremos tratar-se de verso bem longo, somando dezesseis sílabas, paroxítono, com os acentos postos na sílaba um, e na quatro, e na sét'ma e na déc'ma e, em seguida, na déc'ma terceira e na décima sexta:

Ouve-me, Atena, também, / nobre filha de Zeus poderoso!"46

Fala o poeta, logo, em heroicas sequências

de decassílabos, como o fizera em Os brasileidas:

"Quando o poeta desse paradigma

se afasta, p'ra introduzir duas pausas

no verso, que o dividem em três partes

quase iguais, de regra volta no verso seguinte a cair no ritmo inicial, dominante em todo o recitativo:

Dá que possamos / cobertos de glória / voltar para as naves,

Pós grande feito acabarmos / que há de lembrar sempre aos Teucros! Nas traduções esse esquema não é observado com rigor, ocorrendo a tendência a variar de ritmo, pelo deslocamento das pausas no verso,

${ }^{45}$ Odisseia, XXIII, 364-371 (Homero, trad. de Carlos Alberto Nunes, s.d., p. 481).

${ }^{46}$ Os versos adaptam trecho do item $O$ bexâmetro, do Ensaio sobre a poesia épica, de Carlos Alberto Nunes, incluído na edição de seu poema Os brasileidas (Nunes, s.d., p. 38-39). 
com o que se evita a monotonia, de possível desagrado ao ouvido moderno." ${ }^{47}$ E segue-se uma longa pausa.

Põe-se a ditar, em seguida, os versos alados da Ilíada vindos da boca de Pátroclo, para Heitor, em tom débil: “'Ora outra coisa te quero dizer, guarda-a bem no imo peito: não tens, também, muito tempo de vida, que já se aproxima de ti o Fado implacável e a sombra da lívida Morte.

Às mãos de Aquiles terás de morrer, o impecável Eácida'. Pós ter falado, cobriu-o com o manto de trevas a Morte, e a alma, dos membros saindo, para o Hades baixou, lastimando a mocidade e vigor que perdera nessa hora funesta." 48 Lança ele, então, com um tom eloquente, de Heitor esta fala, co’os pés marcando o tal ritmo dactílico caro a si mesmo: "Pobre de mim! É bem certo que os deuses à morte me votam. Tive a impressão de que o forte Deífobo estava a meu lado, mas na cidade se encontra; foi tudo por arte de Atena. Inevitável, a morte funesta de mim se aproxima. Há muito tempo, decerto, Zeus grande e seu filho frecheiro determinaram que as coisas assim se passassem, pois eles, sempre benévolos, soíam salvar-me; ora o Fado me alcança. Que, pelo menos, obscuro não venha a morrer, inativo; hei de fazer algo digno, que chegue ao porvir, exaltado." 49

E ressuscita, depois, pelas mãos do legista, o corpo forte de Heitor; assombrados ficamos, Jaa e o copista, e decidimos libar a alguns deuses olímpios presentes em nossas mentes unidas; mas antes, alertas, lembremos a concepção crítica, vivo argumento de Oliva

Neto, que passo a cindir em dez sílabas postas em linha: "Tendo-se em vista a importância que têm metro e ritmo na linguagem poética e tomando-os como critério para criticar tradução, é Nunes quem heleniza, nos termos de Pannwitz, metricamente o português ao nossa língua aproximar do hexâmetro grego. Como compositor, em nossa língua, de hexâmetros datílicos, o poeta reavivou tradição recente e pouco

\footnotetext{
${ }^{47}$ Nunes (s.d., p. 39).

${ }^{48}$ Iliada, XVI, 850-854 (Homero, trad. de Carlos Alberto Nunes, s.d., p. 374-75).

${ }^{49}$ Ilíada, XXII, 297-305 (Homero, trad. de Carlos Alberto Nunes, s.d., p. 479).
} 
frequentada." ${ }^{50} \mathrm{E}$ assim findo a leitura.

Ocorre-me, após, por sopro de íntima fonte,

perspectiva diversa de vista, alcançada:

o verso silábico-acentual não é tão estranho

à tradição vernácula, como bem mostra Eugênio

da Silva Ramos, o Péricles. ${ }^{51}$ Chamo, a seguir, o Alvarenga,

para evocar uma folga bucólica, em ritmo trocaico:

"Deste bosque alto e sombrio

Sobre a margem da floresta,

Vinha Glaura pela sesta

Vale e rio enamorar.

Tua Dríade a chamava,

Oh mangueira oh dias belos!

E entre pomos amarelos

Me esperava a suspirar." 52

Passo a pensar: o que helenizar se procura

pode não ser o que um outro vislumbra em sua tarefa...

Nesse momento voltamos a ouvir

Carlos Alberto Nunes, a queixar-se:

"Expio, no Hades, as imperfeições

que tenho, e, tradutor, devo ter tido;

ouço, sempre e bem demoradamente,

as acusações de verso alongado,

nem sempre feliz, parente da prosa

e monótono, de dezesseis sílabas;

careço de mais me ter dedicado

à teoria de minhas traduções:

fiz muito, e todo esse muito que fiz

não bastam para o meu justo lugar.”

Segue-se o mais demorado silêncio;

Diante do hiato, me ponho a dizer:

"em boca fechada não entra mosquito

mas quem cala consente." 53

E Catulo me vem, segundo Oliva:

"Se na boca fechada tens a língua,

todos os frutos perderás do amor.

Vênus se alegra com verbosa fala.

\footnotetext{
${ }^{50}$ Os versos correspondem, com alguma adaptação, a excertos do item Carlos Alberto Nunes, incansável tradutor, do texto Breve anatomia de um clássico (Oliva Neto, 2014, p. 42-43).

${ }^{51}$ Ver o artigo "Os princípios silábico e silábico-acentual", de Péricles Eugênio da Silva Ramos (Ramos, 1959, p. 23-31).

${ }^{52}$ Fragmento do poema $A$ árvore, de Silva Alvarenga (2005, p. 284).

${ }^{53}$ Poema Mas, de meu livro Rótulo, de 1990 (Tápia, 2017, p. 299).
} 
$[\cdots]^{354}$

Retorno, atento, à veemente defesa de Nunes pelo lembrado João Angelo, acerca da ideia de prosaísmo e lentidão a seu verso atribuída: "O verso será de fato prosaico e monótono se for lido sem cesura, à martelada. A cesura no hexâmetro datílico português divide-o em terços ou hemistíquios que são, eles mesmos, metros bem conhecidos na tradição poética lusófona." ${ }^{55}$

Eis que retoma sua fala, pulsante, o epopeico poeta: "Meus longos e perseverantes feitos hão de ter contribuído para a atual convergência de uso de metros clássicos em recriações de poesia antiga. Mas me animo ao dizer e ouvir, de novo, versos de meu próprio poema épico, a epopeia nacional, camoniana Ilíada de embates tropicais: 'Levanta-se do oceano a rósea Aurora, flores rubras nos montes desparzindo. Suspensa jaz a redondeza. Rola dos borés a chamada clangorosa por toda a Guanabara, e a voz netúnia de encontro aos areais suspira e geme. Torva, a distância, alastra-se a cuquiada, concitando guerreiros para a luta." 56

É quando, em libação de palavras fluidas, esparge Jaa estes versos, de seu célebre Hesíodo: "Pelas Musas e pelo golpeante Apolo há cantores e citaristas sobre a terra, e por Zeus, reis. Feliz é quem as Musas amam, doce de sua boca flui a voz. Se com angústia no ânimo recém-ferido alguém aflito mirra o coração e se o cantor servo das Musas hineia a glória dos antigos

\footnotetext{
${ }^{54}$ Versos do poema 55, de Catulo (Oliva Neto, 1996, p. 103).

${ }^{55}$ Os versos provêm, com alguma adaptação, de excerto de Oliva Neto (2014, p. 198).

${ }^{56}$ Excerto do Canto IV de Os brasileidas (Nunes, s.d., p. 139).
} 
e os venturosos Deuses que têm o Olimpo, logo esquece os pesares e de nenhuma aflição se lembra, já os desviaram os dons das Deusas." ${ }^{57}$

Optamos, então, por deixar o Érebo, mudos, e caminhar rumo à beira do mundo vivente, onde intentamos, em rede, uma videoconversa com valentes autores amigos, distantes em corpo. Tendo evitado o azeitoso rio Lethe, com plena Memória, ${ }^{58}$ eu e Jaa nos sentimos deveras saudosos, por nosso apego aos eternos mestres deixados; as amizades promovem a continuidade entre a terra e o Hades, o mundo dos vivos e o mundo dos mortos. ${ }^{59}$

Jaa reflete: "penso, em mínima suma, que se devem assegurar coerência, clareza e acribia à transposição, para a língua vernácula, do sistema reiterativo e inter-referente de imagens e de noções míticas..." ${ }^{00}$

Chegados ao local do limite antes transposto, sentamo-nos, quietos, diante da tela brancofluente. Em facetado cristal, com imagens de múltipla origem, surgem as faces telepresentes de Christian Werner, André Malta, Leonardo Antunes e Adriane Duarte, ao vivo e em cores. A fala inicio, rememorando em soneto a trégua entre aqueus e troianos obtida pelo rei Príamo, obra do poeta irlandês Michael Longley, diante de luta alongada na ilha esmeralda:

\section{CESSAR-FOGO}

\section{I}

Relembrando o próprio pai, lacrimoso, Aquiles

Tomou a mão do velho rei; com gentileza Afastou-o, mas Príamo abraçou-lhe os pés:

Choraram, e a tenda inundou-se de tristeza.

${ }^{57}$ Torrano (2003, p. 111).

${ }^{58}$ Sobre a mitologia da Memória e do Esquecimento, veja-se breve passagem de Mircea Eliade em Mito e Realidade (1972, p. 109).

${ }^{59}$ Sobre a afirmação, ver Malta (2006, p. 279).

${ }^{60}$ Os versos provêm, com alguma adaptação, de excerto do texto $A$ dialética trágica na Oresteia de Ésquilo, de Jaa Torrano (2004, p. 14). 
II

Tendo nas mãos o corpo lavado de Heitor, Aquiles, que respeito pelo rei nutria, Embrulhou-o em túnica, como presente A ser ofertado a Troia ao raiar do dia.

\section{III}

Cearam juntos e, então, admiraram a

Beleza um do outro, como o fariam amantes Aquiles qual um deus, Príamo ainda belo E pleno de prosa, ele que suspirara antes:

\section{IV}

"Faço o que devo: posto de joelhos me humilho;

Beijo a mão de Aquiles, que aniquilou meu filho." ${ }^{61}$

Primeiro responde André, que verteu cantos de Homero em versos compostos de dois redondilhos maiores, a recitar a palavra de Príamo, que suplicava por seu guerreiro maior, o ultrajado cadáver: "O grande Príamo entra sem ser percebido, e para; com as mãos agarra os joelhos de Aquiles, e as mãos lhe beija, terríveis, cruentas, que tinham lhe matado muitos filhos." ${ }^{\prime 2}$ E segue dizendo: “Heitor! É por causa dele que venho às naus dos acaios, pra resgatá-lo de ti. Trago um imenso resgate.

Respeita os deuses, Aquiles, e te apieda de mim, lembrando-te de teu pai. Sou mais digno de piedade: ousei o que outro mortal sobre a terra nunca ousou - levar as mãos do varão que matou meu filho à boca."”63

Indagado do labor tradutório, ele nos fala de oralidade e de sua opção para uso do verso:

"Numa tradução que almeja / ser simples e ser poética (em que 'poético' tem / um sentido mais visual e conceitual do que / um sentido musical) a utilização do verso / foi um critério importante; revela a preocupação / rítmica, embora alusiva. O metro que propusemos / é mais uma tentativa de encontrar em nossa língua / um equivalente para o hexâmetro grego, tão / estranho às nossas medidas.

\footnotetext{
${ }^{61}$ Tápia, tradução de poemas irlandeses (2006, p. 97).

${ }^{62}$ Ilíada, XXIV, 377-379 (Homero, trad. de André Malta, 2006, p. 389).

${ }^{63}$ Iliada, XXIV, $501-506$ (ibid., p. 390).
} 
Trata-se de linha elástica / e maleável, de 14 até 17 sílabas, / em cuja base se encontram duas redondilhas maiores, / metrificadas, porém, com mão leve e imprecisa / sem a cesura de praxe. A validade do emprego / do verso básico de sete sílabas - o qual / não tem tradição heroica entre nós - reside no / fato de ser largamente observado na poesia / popular e oral e assim se aparentar, de algum modo / à épica grega, além de servir a meu propósito / de procurar o que é simples." ${ }^{64}$ Assim disse o bi-heptassílabo autor, que em seguida nos oferece seus versos do nono canto da Ilíada - a fala do chefe Agamêmnon sobre a áte, a Aquiles: "'Mas vamos, Aquiles, doma / teu grande ânimo. Não deves ter entranha piedosa: / mesmo os deuses são flexíveis - e deles são bem maiores / a virtude, a honra e a força. A eles com os incensos, / com os suaves clamores, a libação e a gordura, / os homens por aqui aplacam, suplicantes, quando alguém / cai em transgressão e falta. Pois as Súplicas são mesmo / filhas do grandioso Zeus, claudicantes, enrugadas / e estrábicas dos dois olhos, e que ainda se preocupam / em seguir a Perdição. Mas a Perdição é ágil, / robusta, e por isso corre muito mais que todas elas, / e é a primeira em toda a terra a prejudicar os homens - / que aquelas, vindo atrás, curam."”

Surge, logo, em novo quadro na tela brilhante, o jovem Leonardo Antunes, que nova proposta métrica traz para recriação da epopeia; isto diz ele, a nosso pedido, em linhas cindidas: "O método escolhido: traduzir cada hexâmetro dactílico de Homero por dois versos decassílabos vernáculos. A solução de Malta inspirou-me a adotar dois decassílabos.

Há quatro vantagens na solução:

o decassílabo é o metro canônico da épica em Português; dois decassílabos oferecem espaço suficiente para todo o conteúdo semântico, em um trabalho também preocupado com a estética, sem precisar de inversões e outros artifícios que

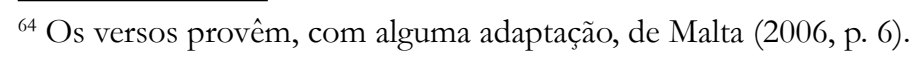


pudessem comprometer a clareza;

a articulação interna do hexâmetro

dactílico, que se divide em dois

hemistíquios, em muitos casos já

organiza o conteúdo do verso

em duas partes, que são recriadas

em Português em dois versos distintos;

poderia usar quantos decassílabos

fossem necessários, mas preferi

a correspondência 2 para 1:

'Ira de Aquiles, filho de Peleu, deusa, concede que eu celebre em canto, ira fatal que aos acaios impôs

uma miríade de sofrimentos;

muitas almas de força e valentia

fez descender para a casa de Hades;

almas de heróis cujos corpos sem vida

relegou como espólio para os cães

e de banquete às aves de rapina.

Assim cumpria-se o plano de Zeus

desde o primeiro momento em que os dois

por força da discórdia se apartaram,

o Atrida, soberano de varões,

e o filho de Peleu, divino Aquiles."

Apresento, também, versos da minha

Miríade, um épico composto em

torno do número 10: serão 100

histórias, cada uma com 10 estrofes

de 10 versos de 10 sílabas, num

total de 10.000 versos. Eis o início

do poema 002, pastiche da Iliada:

'I

Otávio Augusto Motta, 33, conhecido por todos no escritório

como 'o melhor dentre os publicitários',

não lera nunca a 'Ilíada' de Homero,

mas seu coach lhe havia dito a história,

que conhecera de segunda mão

por meio de um resumo no best-seller

'Liberte seu guerreiro interior:

5 macetes do heroísmo grego

para alcançar melhores resultados'. 
II

Por conta disso e por se ter achado

o mais perfeito duplo para Aquiles, deixou-se finalmente acometer

pela fúria que há tempos refreava

usando psicotrópicos diversos.

Partiu para o trabalho àquele dia

deixando de tomar seu Rivotril, cansado após três meses de projeto,

durante os quais, segundo contaria,

levou nas costas toda a sua equipe. ${ }^{65}$

Soam risos; diz Jaa, dando graças:

"Musas inspiram cantores

que inspiram os ouvintes

que inspiram outros ainda

e outros e outros e outros

tal qual a pedra magnética

que imanta anéis de ferro

que imantam outros anéis

e outros e outros e outros."

Digo, em seguida, versos de outro contexto pinçados:

"o nome e a ideia

sobrepõem-se aos

cacos

do tempo

desarruinando o passado" ${ }^{97}$

Chega a vez de ouvirmos os feitos de Christian, que por anos lançou-se a verter Odisseia e Ilíada, baseando-se na natureza oral dos poemas

e no uso de expressões formulares, às quais se refere:

"Busco, na manutenção desse meio expressivo intrínseco

a uma forma tradicional de comunicação,

o meio de trazer o mundo épico aos leitores de hoje,

que poderão experimentar um distanciamento

significativo de seu tempo, lugar e linguagem

cotidiana por meio de uma combinação

particular de familiaridade e estranheza". ${ }^{68}$

\footnotetext{
${ }^{65}$ Os versos provêm, com alguma adaptação, de Antunes (2018).

${ }^{66}$ Os versos são do poema Pedra magnética, da seção Proêmio: agenda sem data, de Jaa Torrano (2017, p. 18).

${ }^{67}$ Os versos integram o poema Nome, do livro Expirais, de 2017 (Tápia, 2017, p. 95).

${ }^{68}$ Os versos adaptam (por vezes, parafraseiam) excertos de Werner em Da tradução (2018a, p. 46).
} 
Divago pensando que em tal equação talvez se defina o traço marcante de cada diversa versão tradutória; e volto ao instante anunciado no quadro luzente: "“a poesia é, ela mesma, a permanência do mundo dos heróis: congela o momento da morte de um guerreiro cujo nome, sem ela, desapareceria. Resta ao guerreiro participar de um poema no qual a violência é, de alguma forma, transformada em beleza." ${ }^{69}$ Ouvimos, depois, esta fala do Atrida a Nestor, na Ilíada, em versos livres por Christian ditados:

" De novo vences os filhos de aqueus no discurso, ancião. Oxalá, por Zeus pai, Atena e Apolo, tivesse eu dez conselheiros aqueus desse porte: então rápido se vergaria a cidade do senhor Príamo, conquistada e pilhada por nossas mãos. Dores deu-me, porém, Zeus, o Cronida porta-égide que me lança em brigas e disputas infrutíferas. Pois eu e Aquiles, por causa de uma jovem, pelejamos com palavras confrontantes [...]"'70

Tem lugar, logo após, evocando a violência feita beleza, o dito de Aquiles, divino, para Heitor, já caído:

"Morra, meu finamento receberei quando quiser

Zeus completá-lo; ele e os outros deuses imortais.”

Sobre o trabalho, esclarece Werner sua busca:

"procuro conferir às traduções

as características principais

de clareza, fluência e poeticidade.

A estranheza - necessária para que

o leitor sinta que entra num mundo muito

diferente do seu - não deve impedir

que se entre no mundo que é recriado.

A 'linguagem especial' se mostra pelo uso de adjetivos compostos por justaposição, para reprodução dos epítetos: 'caro-a-Ares', 'alvos-braços', 'doma-cavalo'...”72

E Christian prossegue a leitura, a nós, dos versos seguintes, que congelam cena terrível depois de morte violenta:

\footnotetext{
${ }^{69}$ Os versos adaptam (por vezes, parafraseiam) excertos de Werner em Uma poética da (i)mortalidade na Introdução de sua tradução à Ilíada (2018b, p. 25).

${ }^{70}$ Ilíada, II, 370-374 (Homero, trad. de Christian Werner, 2018, p. 115).

${ }^{71}$ Iliada, XXII, 365-366 (ibid., p. 609).

${ }^{72}$ Os versos adaptam excertos de Werner (2018a, p. 44, nota 66).
} 
"Falou, puxou a lança brônzea para fora do cadáver, colocou-a ao lado e retirou as armas dos ombros, sangrentas. Outros filhos de aqueus afluíam em volta e contemplavam o porte e a beleza admirável de Heitor: todo que dele se acercava o feria." ${ }^{73}$

Finda a fala, chamamos ao centro da tela a vivaz Adriane Duarte, a dar sua voz à poeta inglesa Alice Oswald. "Ela, em sua obra Memorial. An excavation of the Iliad", diz-nos Adriane, "relê a Ilíada da perspectiva dos guerreiros que morrem no poema homérico, dando destaque às vítimas da guerra. Com isso, celebra sua memória, diluída ao longo da epopeia, em que a ira de Aquiles pontifica. Memorialé um poema contínuo sem pontuação, cuja primeira seção consiste em uma litania de nomes de 213 homens (e um cavalo, Pédaso) mortos no decorrer do poema de Homero." 74 Segue-se a estrofe inicial de Memorial, traduzida: "O primeiro a morrer foi PROTESILAU Um homem lúcido que se lançou na escuridão Com quarenta naus negras deixou para trás sua terra Homens zarparam com ele daquelas colinas floridas Onde a relva tudo regenera Píraso Íton Ptéleo Ántron Morreu em pleno ar pulando o primeiro para a praia Deixou a casa meio-erguida A esposa do lado de fora a arranhar a face Podarco seu irmão menos dotado Assumiu o comando mas isso já faz tempo Jaz agora sob a terra negra há mais de mil anos"75

Imersos no mais presente dos tempos, temos notícia, ligados às ondas fluentes do oceano das redes virtuais, de possível contato, voltado ao futuro, com Trajano Vieira, que ora anuncia sua Ilíada, inédita, a ser publicada no ano corrente; a nosso pedido, o tradutor oferece a atual versão de seus versos para cena de Príamo e Aquiles: "'Sê pio, Aquileu, respeita os numes, lembra

\footnotetext{
${ }^{73}$ Ilíada, XXII, 367-371 (Homero, trad. de Christian Werner, 2018, p. 609).

${ }^{74}$ Os versos adaptam excertos de Duarte (2018), incluindo-se parte de citação, traduzida, de Carolin Hahnemann.

${ }^{75}$ Ibid.
} 
de teu pai! Sou merecedor de mais piedade, pois suportei no mundo o que ninguém suporta, beijar a mão do matador do próprio filho.'

No herói desperta o anseio de chorar o pai.

Tomando suas mãos, acomodou o ancião.

A dupla rememora, um lamenta Heitor massacrador, prostrando-se aos pés de Aquiles, que ora pranteia o pai, ora pranteia Pátroclo.

E seus gemidos ecoavam pela casa.

Prazer do pranto saciado, coração e corpo já vazios de qualquer anseio, o herói sentou no trono, alçando a mão do velho, comiserando a coma branca, a barba branca.

Enfim lhe dirigiu alígeras palavras:

'Muita tristeza pesa em teu coração.

Quanta ousadia vir sozinho às naus argivas e olhar nos olhos quem matou inumeráveis filhos! Um coração de ferro tens em ti." ${ }^{\text {"76 }}$

E, ao fim da jornada, em momento de volta ao início de tudo, evocam-se os versos primeiros da Ilíada: "A fúria, deusa, canta, do pelida Aquiles, fúria funesta responsável por inúmeras dores aos dânaos, arrojando magnas ânimas de heróis ao Hades, pasto de matilha e aves. O plano do Cronida se cumpria, desde o momento em que a lide afasta o atrida, líder do exército, de Aquiles. Mas que nume impôs a desavença aos dois? O filho de Latona e Zeus, que extravasando bile contra o rei alastra peste amarga no tropel, e a turba morre. [...]"

Ao despedirmo-nos, todos, com alma tranquila, entrevimos mosaicos de cenas vibrantes: desenhos densos da Ilíada recriada em quadrinhos velozes pela Tereza Virgínia Ribeiro Barbosa e por Andreza Caetano e Paulo Corrêa; ${ }^{78}$ em balões flutuantes, os ditos ecoam - por obra de Hermes, Apolo e Memória, que a tudo assistiam em nossas mentes sensíveis, viventes de corpo e de alma.

\footnotetext{
${ }^{76}$ Iliada, XXIV, 503-521. Trajano Vieira enviou-me, a meu pedido, excerto dos cantos I e XXIV, em sua tradução inédita, ainda em processo de revisão, a ser publicada durante o ano de 2019.

${ }^{77}$ Ilíada, I, 1-11. Tradução inédita de Trajano Vieira (ver nota 76).

${ }^{78}$ Referência a Barbosa, Caetano e Bagnariol (2012).
} 


\section{REFERÊNCIAS}

ALVARENGA, Manuel Inácio da Silva. Obras poéticas. Introdução, organização e fixação de texto de Fernando Morato. São Paulo: Martins Fontes, 2005.

ANTUNES, Carlos Leonardo Bonturim. Três modos de recepção dos clássicos. Revista Re-Produção, n. 5, 2018. Disponível em: http://www.casaguilhermedealmeida.org.br/revistareproducao/ver-noticia.php?id=100. Acesso em: 31 mar. 2019.

BARBOSA, Tereza Virgínia R.; CAETANO, Andreza; BAGNARIOL, Piero. Ilíada de Homero. Traducão em quadrinhos. Belo Horizonte: RHJ, 2012.

CAMPOS, Haroldo de. Crisantempo. São Paulo: Perspectiva, 1999.

CAMPOS, Haroldo de. Da tradução como criação e como crítica. In: TÁPIA, Marcelo; NÓBREGA, Thelma M. (Org.). Haroldo de Campos - Transcriação. São Paulo: Perspectiva, 2013, p. 1-18.

CAMPOS, Haroldo de. Ilíada de Homero. São Paulo: Arx, 2002. v. 2.

CAMPOS, Haroldo de. Ilíada de Homero. São Paulo: Mandarim, 2002. v. 1.

CAMPOS, Haroldo de. Para transcriar a Ilíada. In: ; VIEIRA, Trajano. A ira de Aquiles.

São Paulo: Perspectiva, 1994, p. 11-28.

CAMPOS, Haroldo de. Signantia quasi coelum. Signância quase céu. São Paulo: Perspectiva, 1979.

CAMPOS, Haroldo de. Xadrez de estrelas. Percurso textual 1949-1974. São Paulo: Perspectiva, 1976.

DUARTE, Adriane da Silva. Memorial. A Ilíada residual de Alice Oswald. Revista Re-Produção, n. 5, 2018. Disponível em: http:/ / www.casaguilhermedealmeida.org.br/revista-reproducao/ ver-noticia.php?id=101. Acesso em 31 mar. 2019.

ELIADE, Mircea. Mito e realidade. São Paulo: Perspectiva, 1972.

HESÍODO. Teogonia. A origem dos deuses. Tradução de Jaa Torrano. São Paulo: Iluminuras, 2003. HOMERI Opera. Ilias. Thomas W. Allen (Ed.). Oxford: Clarendon Press, 1920. Disponível em: http://www.perseus.tufts.edu/hopper/text?doc=urn:cts:greekLit:tlg0012.tlg001

HOMERO. Ilíada. Tradução de Christian Werner. São Paulo: Ubu, 2018.

HOMERO. Ilíada. Tradução de Odorico Mendes. Prefácio e notas verso a verso de Sálvio Nienkötter. São Paulo: Ateliê; Campinas: Unicamp, 2008.

HOMERO. Ilíada. Tradução em versos de Carlos Alberto Nunes. Rio de Janeiro: Edições de Ouro, s.d.

LOPES, Daniel Rossi Nunes. Xenófanes de Cólofon. Fragmentos. São Paulo: Olavobrás, 2003. 
MALTA, André. A astúcia de Ninguém. Ser e não ser na Odisseia. Belo Horizonte: Impressões de Minas, 2018.

MALTA, André. A selvagem perdição. Erro e ruína na Ilíada. São Paulo: Odysseus, 2006.

NUNES, Carlos Alberto. Ensaio sobre a poesia épica. In: . Os brasileidas. São Paulo:

Melhoramentos, s.d., p. 5-59.

NUNES, Carlos Alberto. Os brasileidas. São Paulo: Melhoramentos, s.d.

OLIVA NETO, João Angelo. Breve anatomia de um clássico. In: VIRGÍLIO. Eneida. Tradução de Carlos Alberto Nunes. Organização, apresentação e notas de João Angelo Oliva Neto. São Paulo: Editora 34, 2014, p. 9-34.

OLIVA NETO, João Angelo. O hexâmetro datílico de Carlos Alberto Nunes: teoria e repercussões. Revista Letras, n. 89, p. 187-204, 2014.

OLIVA NETO, João Angelo. O livro de Catulo. Tradução, introdução e notas. São Paulo: Edusp, 1996.

TÁPIA, Marcelo. Diferentes percursos de tradução da épica homérica como paradigmas metodológicos de recriação poética. 2012. Tese (Doutorado) - Programa de Pós-Graduação em Teoria Literária e Literatura Comparada, Universidade de São Paulo, São Paulo, 2012. Disponível em: http:/ / www.teses.usp.br/teses/disponiveis/8/8151/tde-31082012-090500/pt-br.php Acesso em 31 mar. 2019.

TÁPIA, Marcelo. Poemas irlandeses. Cadernos de literatura em tradução, n. 7, p. 85-107, 2006.

TÁPIA, Marcelo. Refusões. Poesia 2017-1982. São Paulo: Perspectiva, 2017.

TORRANO, Jaa. A dialética trágica na Oresteia de Ésquilo. In: ÉSQUILO. Agamêmnon. Estudo e tradução de Jaa Torrano. São Paulo: Iluminuras, 2004.

TORRANO, Jaa. A esfera e os dias. São Paulo: Annablume, 2009.

TORRANO, Jaa. Divino gibi. Crítica da razão sapiencial. São Paulo: Annablume, 2017.

WERNER, Christian. Da tradução. In: HOMERO. Ilíada. Tradução de Christian Werner. São Paulo: Ubu, 2018a, p. 43-66.

WERNER, Christian. Introdução. In: HOMERO. Iliada. Tradução de Christian Werner. São Paulo: Ubu, 2018b, p. 13-42. 
